\title{
Tankebilder er min sovemedisin
}

\author{
Jeg er en 82-årig legepensjonist. Jeg skriver fordi jeg har snublet over en måte som får meg til å sovne \\ uten medisin, min form for «å telle sauer».
}

> Se kommentar side 2379

Jeg fikk Imovane ved en universitetsklinikk for 12 år siden. Jeg har vekslet mellom $7,5 \mathrm{mg}$ og 3,75 mg og mange ganger prøvd å slutte, uten å klare det. I Norsk legemiddelhåndbok står det at behandlingen ikke bør vare mer enn 2-4 uker.

Jeg vet ingenting om søvnforskning og har ingen erfaring med pasienter med søvnvansker. Jeg har kjent folk som sovnet av aftenbønn og av meditasjon, men jeg er ikke troende og kan ikke noe om meditasjon. Jeg tok utgangspunkt i aftenbønnen, for jeg kjenner da kristen kultur. Hvem ville jeg da ha bedt for? Kone og fire voksne barn! Etter hvert fant jeg frem erindringsbilder fra barna var små, «bilder» som var fylt av kontakt, glede og ro. Min eldste datter hadde tremånederskolikk og skrek i timevis. Jeg la henne på magen på hendene mine og gikk langsomt opp og ned på gulvet. Da sovnet hun rolig. Den yngste datteren våknet, var redd og gråt om kvelden. Jeg klatret opp i overkøya til henne. Hun grep mitt ene øre, puttet totten på samme hånd i munnen og sovnet straks. Min yngste sønn gråt som baby fordi han var kald og våt. Jeg la han på magen min, han sovnet straks. Den eldste sønnen var rund og alltid blid. Han stupte og svømte under vann da han var 3-4 år gammel, før han kunne svømme. «Bildet» av min kone er første gang jeg så henne. Hun sang solo med en klar og ren sopran, var blond og slank i en stilig kjole.

Jeg sluttet med Imovane og tar nå ingen sovemedisin. Så snart jeg blir varm i sengen, tenker jeg etter tur på disse fem episodene og koser meg med erindringsbildene. Som regel må jeg ta to-tre runder med «bildene» før jeg sovner. Jeg er oppe og later vannet to-tre ganger om natten. Da sovner jeg oftest igjen etter bare noen «bilder». Med Imovane lå jeg i timevis før jeg sovnet igjen.

Hvis jeg har noen særlig assosiasjoner til «bildene», får jeg ikke sove. Det ser ut som det er viktig at «bildene» er uforandret og får være uforstyrret. Min kone sier at jeg sover bedre enn på tablettene. Det har gått mange uker, og det virker bare bedre.

Dette er lite vitenskapelig og kanskje ikke noe nytt. Min utmerkede fastlege syntes jeg skulle skrive, for det kunne kanskje inspirere andre.

\section{2-årig legepensjonist}

Mottatt 7.8. 2013 og godkjent 22.8. 2013. Redaktør: Erlend Hem.

\section{Kommentar}

\section{Søvn}

Pensjonisten har vært avhengig av å ta sovemedisin i 12 år, uten tilfredsstillende effekt, men nå benytter han tankebilder for å få sove. Og effekten er veldig god. Slike beretninger er interessante og viktige.

Vi vet egentlig veldig lite om hvilke metoder og knep folk benytter for å oppnå god søvn. «A telle sauer» er et velkjent knep, men om det hjelper, er uklart og dårlig dokumentert. For oss som jobber med søvnmedisin, er inntrykket at slike råd er lite effektive. Men vi ser jo kun personer som sliter med søvnen, ikke dem som løser søvnproblemene med slike «hjemmelagde» knep.

I mange undersøkelser både nasjonalt og internasjonalt dokumenteres det at søvnproblemer er et omfattende folkehelseproblem. Rundt $10 \%$ av alle voksne sliter med dårlig søvn, og mange barn er også plaget. Over 411000 nordmenn hentet ut resept på sovemedisin i 2011, noe som understreker problemets omfang. Sovemedisiner har veldokumentert effekt ved bruk over en kor- tere tidsperiode. Men langvarig bruk av sovemedisiner frarådes. Grunnene til det er mange. Den viktigste grunnen er at effekten vanligvis taper seg raskt, og etter få ukers daglig bruk opplever pasienten mindre og mindre nytte. Samtidig er det risiko for avhengighet, og også andre bivirkninger. Det er all grunn til å fraråde langvarig bruk av sovemedisiner.

Heldigvis finnes det annen type behandling, som både er langt mer effektiv og uten avhengighetspotensial. Ved kronisk insomni er kognitiv atferdsterapi veldokumentert, og effekten vedvarer over tid. Behandlingen går i korte trekk ut på å begrense tiden i sengen til faktisk søvnlengde og å unngå å bli liggende i sengen hvis man ikke får sove. Mange pasienter med insomni ligger timevis i sengen, frustrert over manglende søvn. Dette skaper en negativ kobling mellom seng og søvn og forverrer søvnvanskene. Har pasienter med dårlig søvn noe å lære av personer som sover normalt? Hvilke knep benytter «normalsovere»?
Det typiske er at personer som sover godt, ikke benytter noen knep, de bare legger seg ned i sengen og lukker øynene. Deretter kommer søvnen av seg selv. Insomnipasienter har derimot ofte mye fokus på søvn og innsovningsmetoder. Det er imidlertid en kjensgjerning at jo hardere man prøver å sove, jo vanskeligere blir det.

Kognitiv atferdsterapi mot insomni er krevende behandling, og ofte ses forverring initialt før bedringen kommer. Rundt $80 \%$ av pasientene responderer positivt. Et ankepunkt mot slik behandling har vært at den er komplisert, tidkrevende og lite tilgjengelig. Det er få behandlere i Norge. Det utprøves derfor selvhjelpsbehandling gjennom internett og bøker $(1,2)$. I en randomisert, kontrollert studie sov insomnipasienter langt bedre og færre brukte sovemedisiner etter å ha lest en norsk selvhjelpsbok (3) sammenliknet med søvnhygieneråd (1). Dette viser at en selvhjelpsbok kan være et lett tilgjengelig og effektivt lavterskeltilbud mot kronisk insomni. 


\section{Bjørn Bjorvatn}

bjorn.bjorvatn@isf.uib.no

Nasjonal kompetansetjeneste for søvnsykdommer

Haukeland universitetssykehus

og

Institutt for global helse og samfunnsmedisin Universitetet i Bergen

Bjørn Bjorvatn (f. 1963) er spesialist i allmennmedisin og professor.

Oppgitte interessekonflikter: Han er forfatter av omtalte selvhjelpsbok.

\section{Litteratur}

1. Bjorvatn B, Fiske E, Pallesen S. A self-help book is better than sleep hygiene advice for insomnia: a randomized controlled comparative study. Scand J Psychol 2011; 52: 580-5

2. Espie CA Kyle SD Williams $C$ et al A randomized, placebo-controlled trial of online cognitive behavioral therapy for chronic insomnia disorder delivered via an automated media-rich web application. Sleep 2012; 35: 769-81.

3. Bjorvatn B. Bedre søvn. Bergen: Vigmostad og Bjørke, 2007.

Mottatt 12.9. 2013 og godkjent 18.9. 2013. Redaktør: Erlend Hem. 